\title{
A Magyar Királyi Honvédség páncélozott eszközökkel felszerelt felderítő csapatai
}

\section{ERDÉLY TERÜLETÉNEK VISSZAVÉTELE}

1939 szeptemberében megkezdődött Hitler „villámháborúja" Lengyelország ellen, amelynek következtében - a német csapatok bevonulásával - az európai határok gyorsan megváltoztak. Ezzel egy időben a Szovjetunió is kihasználta ezt a helyzetet és a csapatai alkalmazásával „kitolta” korábbi határait nyugat felé.

A magyar haderő a HUBA hadrend következő időszakának megfelelően bővült. 1940. március 1-én 3 hadseregparancsnokságot hoztak létre a hadtestek hadműveleteinek irányítására. Az 1. hadsereg-parancsnokság Szolnokon (majd az erdélyi bevonulást követően Kolozsváron) települt alárendeltségében a debreceni VI., a kassai VIII. és a kolozsvári IX. hadtestparancsnokságoknak alárendelt csapatokkal. A 2. hadsereg-parancsnokság Budapesten, alárendeltségében a budapesti I., a székesfehérvári II. és a miskolci VII., míg a 3. hadsereg-parancsnokság Pécsről irányította alárendeltjeit a szombathelyi III., a pécsi IV. és a szegedi V. hadtestet és csapatait. A Felvidék visszavételét követően felálításra került a VIII. hadtestparancsnokság, majd a meglévő gyorscsapatok egységesen az I. gyorshadtest alárendeltségébe kerültek. Kárpátalja visszacsatolása után 1939-ben, a sajátos terepviszonyoknak megfelelően, a VIII. hadtest kötelékén kívül felállították az 1. hegyi dandárt.

A 1940. március 1-vel a felső szintű vezetést is korszerűsítették, a trianoni előírások miatt létrehozott honvédség főparancsnokának állását megszűntetve, a hadsereg irányítására, kiképzésére vonatkozó teendőket - az 1938 októbere óta ismét nyíltan működő - vezérkar vette át, a felada-

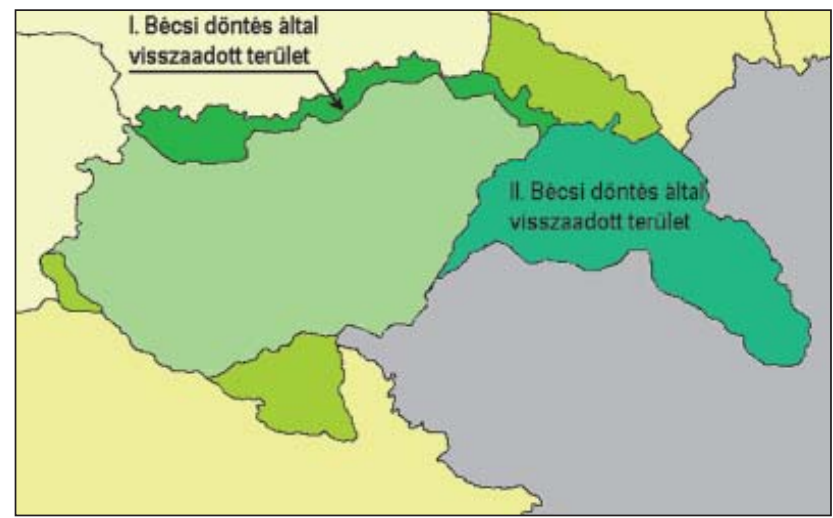

64. ábra. A bécsi döntések által visszakapott területek

tok személyügyi része a Honvédelmi Minisztérium hatáskörébe került. Ezzel megszúnt a katonai vezetés 1922 óta fennáló hármas tagolása.

1940 tavaszától mindennaposakká váltak a magyarromán határincidensek. A magyar kormány a vezérkari főnök javaslatára 1940. május 10-től megkezdte az egyes seregtestek a hadilétszámra való feltöltését, illetve részleges mozgósítás elrendelését. ${ }^{105}$

Erre az időszakra felderítőcsapatokhoz már kezdtek beérkezni a gyártóktól megrendelt 38M Toldi könnyű harckocsik és a 39M Csaba páncélgépkocsik. A kiképzés mielőbbi megkezdése érdekében az első Csaba páncélgépkocsik még csak vaslemezekkel voltak szerelve, de a vezetési-, lő- és harcászati gyakorlatok megkezdéséhez még így is

11. táblázat. A magyar királyi felderítőcsapatok páncélozott járművei 1932-1945

\begin{tabular}{|c|c|c|c|c|c|c|c|c|c|c|c|}
\hline $\begin{array}{l}\text { Megneve- } \\
\text { zése }\end{array}$ & \begin{tabular}{|c|} 
Ke- \\
ze- \\
Iók \\
szá- \\
ma
\end{tabular} & $\begin{array}{c}\text { Har- } \\
\text { ci } \\
\text { tö- } \\
\text { me- } \\
\text { ge } \\
\text { kg }\end{array}$ & $\begin{array}{c}\text { Tel- } \\
\text { jes } \\
\text { hosz- } \\
\text { szú- } \\
\text { ság } \\
\text { mm }\end{array}$ & $\begin{array}{l}\text { Tel- } \\
\text { jes } \\
\text { szé- } \\
\text { les- } \\
\text { ség } \\
\mathrm{mm}\end{array}$ & $\begin{array}{l}\text { Ma- } \\
\text { gas- } \\
\text { ság } \\
\mathrm{mm}\end{array}$ & $\begin{array}{c}\text { Tengelyek/ } \\
\text { Hajtott } \\
\text { kerekek } \\
\text { száma } \\
\text { db }\end{array}$ & $\begin{array}{l}\text { Motor- } \\
\text { teljesítmény/ } \\
\text { Fajlagos } \\
\text { teljesítmény }\end{array}$ & $\begin{array}{l}\text { Max. } \\
\text { sebesség } \\
\text { Ható- } \\
\text { távolság }\end{array}$ & Páncélzat & Fegyverzete & Megjegyzés \\
\hline $\begin{array}{l}\text { 35M Ansaldo } \\
\text { kisharckocsi }\end{array}$ & 2 fö & 3200 & 3150 & 1400 & 1300 & Ict & $43 \mathrm{LE}$ & $\begin{array}{l}42 / 15 \mathrm{~km} / \mathrm{h} \\
120-160 \mathrm{~km}\end{array}$ & $\begin{array}{c}\text { Homlok: } 13,5 \\
\text { oldal: } 8,5 \\
\text { Hátsó } 6\end{array}$ & $\begin{array}{l}2 \times 34 / \mathrm{AM} \\
8 \mathrm{~mm} \mathrm{gpu} \\
150 \mathrm{db}\end{array}$ & $150 \mathrm{db}$ \\
\hline $\begin{array}{l}\text { 38M Toldi I. } \\
\text { közepes } \\
\text { harckocsi }^{\star}\end{array}$ & 3 fö & 2500 & & & & & & $\begin{array}{l}50 \mathrm{~km} / \mathrm{h} \\
200 \mathrm{~km}\end{array}$ & $6-23$ & $\begin{array}{l}1 \times 20 \mathrm{~mm} \\
208 \mathrm{db} \\
1 \times 8 \mathrm{~mm} \\
2400 \mathrm{db}\end{array}$ & \\
\hline $\begin{array}{l}\text { 39M Csaba } \\
\text { páncél- } \\
\text { gépkocsi }\end{array}$ & 4 fö & 5950 & 4520 & 2140 & 2650 & $\begin{array}{c}2 \\
4 \times 4\end{array}$ & $90 \mathrm{LE}$ & $\begin{array}{c}65 \mathrm{~km} / \mathrm{h} \\
150-200 \mathrm{~km}\end{array}$ & $9-13$ & $\begin{array}{l}1 \times 20 \mathrm{~mm} \\
\text { Solothurn } 36 \mathrm{M} \mathrm{n} . \mathrm{pu} \text {. } \\
200 \mathrm{db} \\
1 \times 8 \mathrm{~mm} 36 \mathrm{M} \mathrm{gpu} \text {. } \\
3000 \mathrm{db}\end{array}$ & $\begin{array}{l}1939-61 \mathrm{db} \\
1940-20 \mathrm{db} \\
1941-70 \mathrm{db}\end{array}$ \\
\hline $\begin{array}{l}40 \mathrm{M} \text { Csaba } \\
\text { páncél- } \\
\text { gépkocsi }\end{array}$ & 4 fö & 5950 & 4520 & 2140 & 2650 & $\begin{array}{c}2 \\
4 \times 4\end{array}$ & $90 \mathrm{LE}$ & $\begin{array}{c}65 \mathrm{~km} / \mathrm{h} \\
150-200 \mathrm{~km}\end{array}$ & $9-13$ & $\begin{array}{l}1 \times 8 \mathrm{~mm} 34 / 37 \mathrm{M} \\
3000 \mathrm{db}\end{array}$ & $\begin{array}{l}12 \mathrm{db} \text { R4 és } \\
\text { R4T rádió }\end{array}$ \\
\hline
\end{tabular}




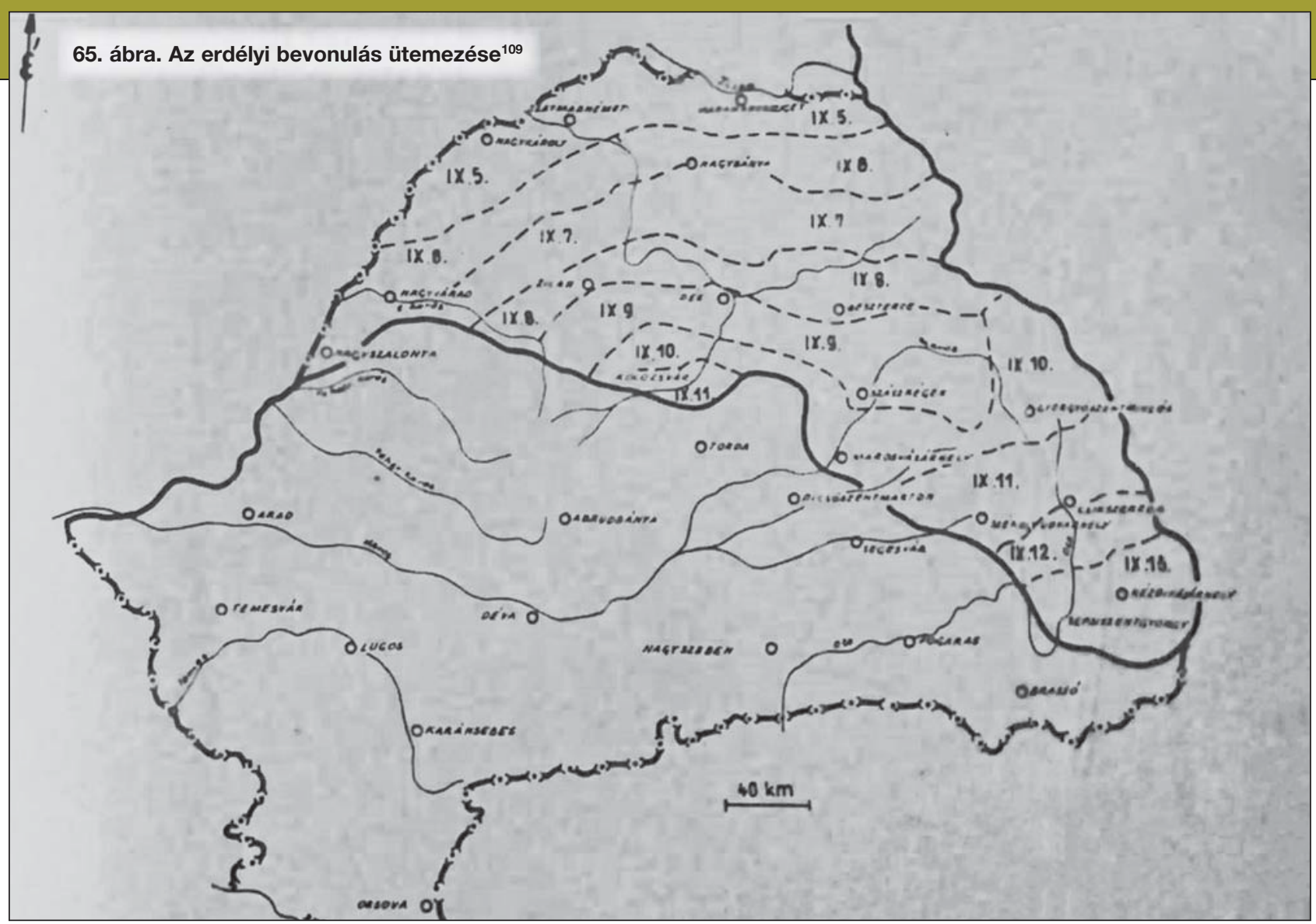

megfeleltek. 1940 nyarára az előírt mennyiségű technikai eszközökkel lassan fel tudták tölteni mind a két gépkocsizó dandár felderítő-zászlóaljait, és a lovasdandárok is megkapták a páncélkocsikat.

Június 26-án a Szovjetunió felszólította Romániát a besszarábiai és bukovinai területek átadására, ami - Németország „békés szemlélődése” mellett - meg is történt. A magyar kormány arra az elhatározásra jutott, hogy kihasználva ezt a helyzetet, követelni fogja a saját területi igényeinek kielégítését, bár - az ideológiai szembenállása miatt - nem kívánt a szovjetekkel közösen fellépni ezek érvényesítésére.

A magyar követelések nyomatékos kifejezésére - önálló erődemonstrációként, mintegy 550 ezer fővel - a három hadseregét felvonultatta a határ mentén és felkészült arra, ha kell, fegyverrel szerzi vissza a trianoni békeszerződés által elcsatolt területeket.

Az Erdély területére bevonulni tervezett 2. és 3. hadseregek sikeres benyomulása érdekében az 1 . távolfelderítő

66. ábra. A honvédség egyik felderítő-zászlóaljnak alárendelt páncélvonata a kolozsvári pályaudvaron, 1940 szeptemberében (Fortepan 12716330)

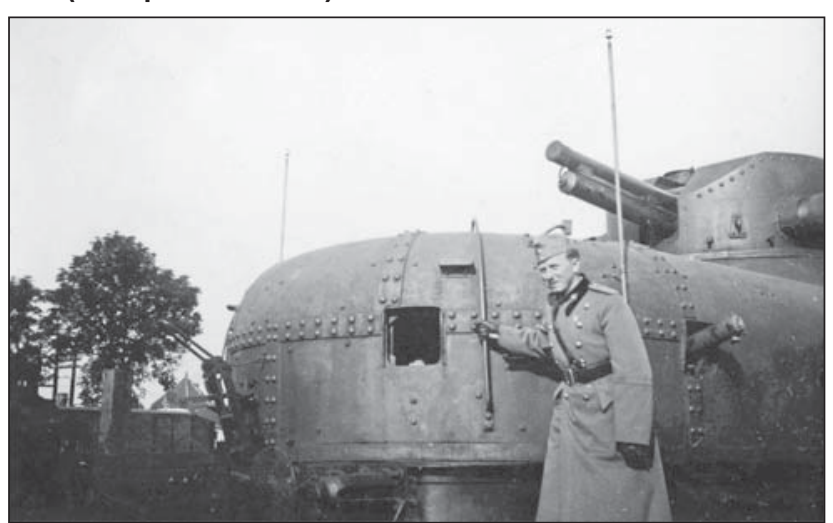

osztály felderítő repülői már 1940. augusztus 8-án megkezdték az intenzív légi fényképezést, hogy a csapatok friss katonaföldrajzi és felderítési adatokkal lássák el. A beérkezett felderítési adatokat azok értékelése után juttatták el a hadseregtörzsekhez, amelyek I/b osztályai tájékoztatták a csapatokat. ${ }^{106} \mathrm{~A}$ későbbiek folyamán - amikor megkapták a korszerű Heinkel 111P távolfelderítő repülőgépeiket - már 6-8000 méter magasságból 30 × 30 cm képméretű légi fényképeket tudtak biztosítani a felhasználóknak, amelyek minden tekintetben kiszolgálták a vezérkar és a csapatok felderítések igényeit.

Hitler azonban nem várta meg a szövetségesei közötti súlyos konfliktus kirobbanását, még kevésbé a tűrte el a számára stratégiai fontosságú román olajmezők veszélyeztetését. Ezért az Olaszországgal közösen újabb döntőbíró-

67. ábra. Kerékpáros alakulatok menete az erdélyi bevonulás során (Fortepan 92546)

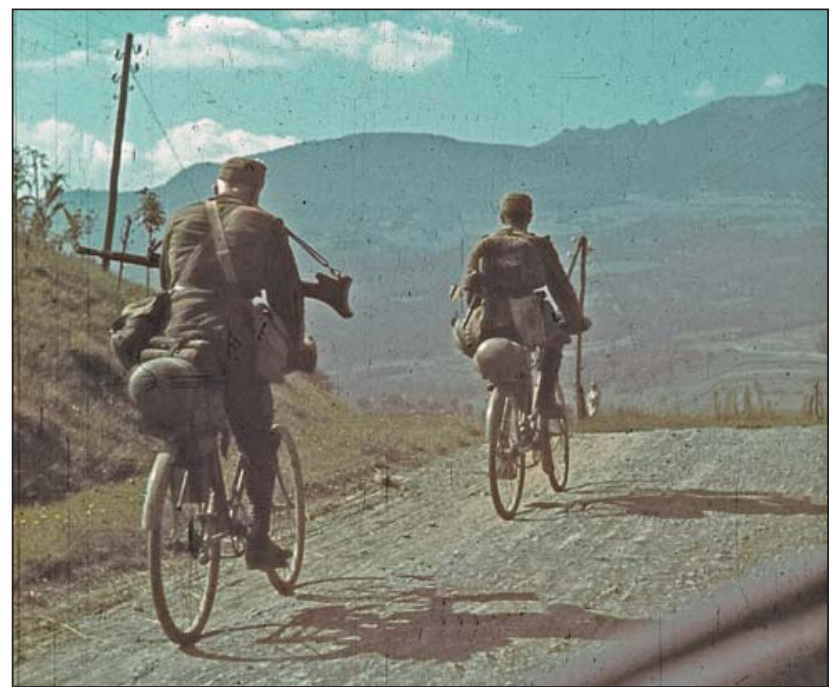




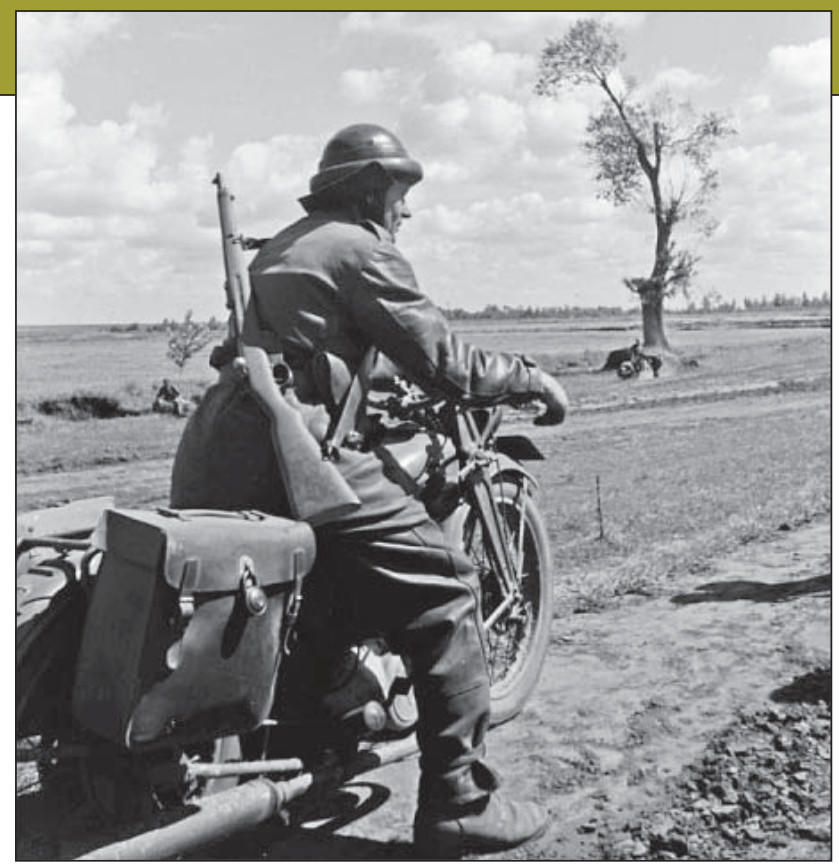

68. ábra. Motorkerékpáros felderítő az erdélyi bevonulás során (Fortepan 42973)

sági tárgyalás után - augusztus 30-án - megszületett a második bécsi döntés, amely szerint Magyarország csak az észak-erdélyi részt kapta vissza a korábbi területéből. Ez a döntés egyik felet sem elégítette ki, de azt kénytelenek voltak elfogadni.

A második bécsi döntéssel Magyarország 43492 négyzetkilométernyi területet kapott vissza, benne Székelyfölddel. Az 1941. évi népszámlálás adatai szerint, a visszacsatolt Észak-Erdélyben 1344000 magyar, 1069000 román és 47000 német lakos élt. Dél-Erdélyben körülbelül 400.000 magyar maradt.

A Magyarországnak ítélt területet a románoknak 14 nap alatt kellett kiüríteniük, $s$ azt a honvédségnek szeptember 5-13. között megszállni. ${ }^{107}$ A Nagyváradon összeült magyar-román katonai bizottság tárgyalásain a közösen meghatározott bevonulási menetrend alapján szeptember 5-én kezdődött a bevonulás és a kiürítés.

A bevonuló magyar csapatok szeptember 5 -én reggel 7 órakor Máramarosszigetnél lépték át a Tiszát. A tervek szerint szeptember 11-én 12 órakor kellett elérniük Kolozsvárt, az egész terület megszállását pedig szeptember 13-án 18 órakor be kellett fejezniük. A magyar erők minden nap reggel 7 órakor kezdhették meg az előrenyomulást, a román csapatoknak pedig azok beérkezése előtt már két órával ki kellett üríteniük a megszállandó területeket. $A$ végrehajtó gyalogos csapatok részére szigorúan $4 \mathrm{~km}$ / órás menetsebességet írtak elő. A feladatok meghatározásánál az alkalmazott gyorsfegyvernemi csapatok menetsajátosságait is figyelembe vették. A lovascsapatok részére maximum 6 , a kerékpáros csapatok részére 8 , a gépkocsizó csapatok tekintetében pedig 12 km/óránkénti menetteljesítményben egyeztek meg. A bevonulás időszaka alatt tilos volt az átadandó terület feletti légi tevékenység és tilos volt az ejtőernyő alegységek alkalmazása is. ${ }^{108}$

Az összeütközések megakadályozása érdekében a magyar félnek át kellett adnia előre a bevonuló csapatok menetvonalát a román katonai hatóságok részére, hogy azok megfelelően tudják szabályozni saját utóvédjeik menetütemét. A megszállás időszakában a bevonuló csapatok zömének igen komoly 40-50, estenként 70-80 km napi menetteljesítmény kellett teljesítenie. Kemény követelményt jelentett a nagytávolságú - 8 nap alatt légvonalban 375 km * mélységű területre - menet végrehajtása, különös tekintettel, hogy a csapatok zöme gyalog, illetve lóvontatású eszközökkel ellátott csapatokat merítette ki. Mindezek ellenére

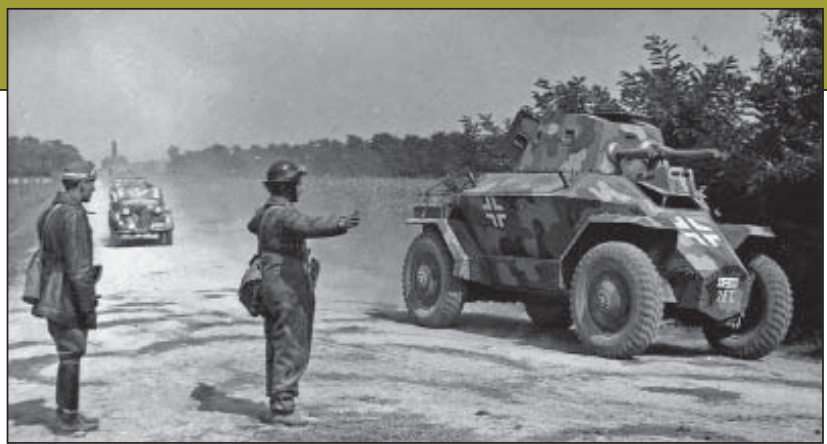

69. ábra. Erdélyi bevonulás, a 2. felderítő-zászlóaljtörzshöz tartozó 39M Csaba páncélgépkocsi és egy ex-lengyel Polski FIAT személygépkocsi 1940 szeptemberében (Fotó: Mujzer Péter)

a csapatok mindennap teljesítették a kitűzött menetcéljaikat és szeptember 13-ra kijutottak a számukra meghatározott körzetekbe, azonban megjegyzendő, hogy a mögöttes lépcsők beérkezése szeptember 18-ig tartott.

Annak érdekében, hogy a meghatározott határidőn belül végre tudják hajtani a kiürített területek megszállását, a Kolozsvár - Dés - Naszód vonal elérése után a Székelyföldre való bevonulást már az I. gyorshadtest csapatai kapták feladatul. ${ }^{110}$

A bevonulást követően a csapatok visszatérhettek helyőrségeikbe, kivéve az I. hadsereg és a gyorshadtest-parancsnokság egyes alárendeltjeit. A VI. és a VII. hadtest, valamint az 1. és a 2. gépkocsizó dandár a helyszínen maradt és biztosította Erdély visszavett területét és az újonnan létrejövő IX. hadtest megalakítását. A felderítőcsapatok a biztosítási időszakban kiképzési feladatokat hajtottak végre.

A Kolozsvár székhelyű seregtest megalakítását követően, a haderőfejlesztés fő erőkifejtését az újonnan létrehozott csapatok megerősítésére fordították, a biztosító csapatok pedig visszatértek saját helyőrségeikbe.

Az erdélyi bevonulás sem hozott igazi harci tapasztalatokat a felderítőcsapatoknak. Azonban lehetőséget biztosított nekik az új harci eszközökkel kapcsolatos tapasztalatok gyűjtésére, alkalmazási lehetőségeik kipróbálására és a fegyverzeti és híradó eszközökkel kapcsolatos tapasztalatok átadására.

Ezek alapján módosítottak a Csaba páncélgépkocsi egyes elemein, mint például a gumiköpenyek kicserélése, a páncélkocsi fütésének javítása, vagy a parancsnoki járművek elkészítése.

A felderítőcsapatok szervezete lassan kialakult. A parancsnoki és legénységi állomány felkészültsége egyre magasabb szintre emelkedett. Ezeknek a tapasztalatoknak a hasznosítására hamarosan, már a 1941-ben sor is került a váratlan délszláv események kapcsán.

(Folytatjuk)

\section{JegYZETEK}

105 Dr. Csima Lajos: Adalékok... p.35

106 Dr. Horváth Csaba alezredes: A magyar harcászati-hadműveleti felderítés története 1918-1990, Felderítő Szemle VII. évfolyam. Emlékszám 2008. november. Kilencven esztendeje önáló a magyar katonai Felderítés és hírszerzés 1918 - 2008. Budapest $p$. 126.

107 Dombrády Lóránd - Tóth Sándor: A Magyar Királyi Honvédség 1919-1945, Zrínyi Katonai Kiadó, Budapest, 1987, p.163.

108 Kiss Gábor Ferenc: A Magyar Királyi Honvédség Gyorscsapatainak alkalmazása 1938-1941, Közép-Európai Közlemények VI. évfolyam 4. szám, 2013/4. No. 23. pp. 119. 109 A Vázlat a dr. Csima Lajos: Adalékok...könyvből készült p. 41. 110 Dr. Csima Lajos: Adalékok... pp. 40-41. 